\title{
MANAJEMEN KEPALA MADRASAH DALAM MENINGKATKAN MUTU TENAGA PENDIDIK DI MTS NW SELAYAR
}

\author{
Sanjaya Perdana Zain \\ STIT Palapa Nusantara \\ sanjayaperdanazain92@gmail.com
}

\begin{abstract}
Management as "the process of utilizing all resources that support Muslims, educational institutions and others, both hardware and software". Effective and effective to achieve certain goals. The headmaster is a leader who cannot be fulfilled by people without consent. Whoever is appointed to be the principal must be determined through certain procedures and requirements such as: educational background, experience, age, rank and integration. Therefore the madrasa head is essentially official, because the appointment is through a process and procedure in accordance with applicable regulations. Educators are professionals who are involved in the learning process, learning process, training and guidance, as well as conducting research and community service. Research using research in this study uses qualitative. In this question, the data related to the problem is discussed and published by the interpretiveinterpretative. Madrasa head management in improving the quality of teaching staff in the MTs NW Selayar is carried out by involving educators in scientific forums (seminars, training, training, workshop and courses), further studies, MGMP revitalization, welfare benefits, providing support to access new information, buying books new policies that support the performance of educators and include teachers in the professional certificate program.
\end{abstract}

Keywords: Madrasah Head Management, Quality of Educators

\begin{abstract}
Abstrak : Manajemen sebagai "proses pemamfaatan semua sumberdaya yang dimiliki umat islam, lembaga pendidikan dan lainnya, baik perangkat keras maupun lunak. Pemamfaatan tersebut dilaksanakan melalui kerjasama dengan orang lain secara efektif dan efesien dan produktif untuk mencapai tujuan tertentu. Kepala madrasah adalah jabatan pemimpin yang tidak bisa diisi oleh orang-orang tanpa didasarkan atas pertimbangan-pertimbangan. Siapapun yang diangkat menjadi kepala sekolah harus ditentukan melalui prosedur serta persyaratan-persyaratan tertentu seperti: latarbelakang pendidikan, pengalaman, usia, pangkat dan integritas. Oleh sebab itu kepala madrasah pada hakikatnya adalah pejabat formal, sebab pengangkatnya melalui suatu proses dan prosedur yang didasarkan atas peraturan-peraturan yang berlaku. Tenaga Pendidik merupakan tenaga profesional yang bertugas merencanakan dan melaksanakan proses pembelajaran, menilai hasil pembelajaran, melakukan bimbingan dan pelatihan, serta melakukan penilitian dan pengabdian kepada masyarakat. Pendekatan penelitian yang peneliti gunakan dalam penelitian ini adalah pendekatan kualitatif. Dalam pendekatan ini datat-data yang terkait dengan masalah yang di bahas dan dijabarkan secara deskriftif-interpretatif. Manajemen kepala madrasah dalam meningkatkan mutu tenaga pendidik di MTs NW Selayar dilaksanakan dengan mengikutkan para tenaga pendidik dalam forum ilmiah (seminar, diklat, lokakarya, wokshop dan kursus), studi lanjut, revitalisasi MGMP, tunjangan kesejahteraan, penyediaan fasilitas penunjang seperti penyediaan fasilitas
\end{abstract}

Manazhim : Jurnal Manajemen dan Ilmu Pendidikan

Volume 2, Nomor 1, Februari 2020; 54-69

https:// ejournal.stitpn.ac.id/index.php/manazhim 
internet untuk mengakses informasi baru, pembelian buku baru yang menunjang terhadap kinerja tenaga pendidik dan mengikutkan guru dalam program sertifikat profesi.

Kata Kunci: Manajemen Kepala Madrasah, Mutu Tenaga Pendidik

\section{PENDAHULUAN}

Undang-undang nomor 20 tahun 2003, tentang Sistem Pendidikan Nasional, pasal 39 ayat 1 . Tenaga Pendidik merupakan tenaga profesional yang bertugas merencanakan dan melaksanakan proses pembelajaran, menilai hasil pembelajaran, melakukan bimbingan dan pelatihan, serta melakukan penilitian dan pengabdian kepada masyarakat. ${ }^{1}$

Bila mengacu pada tugas tersebut, tenaga pendidik merupakan guru yang profesional dalam menyampaikan materi pembelajaran kepada para peserta didiknya, dengan melaksanakan tugas dan kewajibannya sebagai pendidik.

Dengan adanya peraturan dari pemerintah tentang tenaga pendidik atau guru profesional, tidak luput dari pengawasan dan pengaturan dari kepala madrasah yang menjadi nahkoda dalam pendidikan.

Keberhasilan sebuah lembaga pendidikan mewujudkan kedisiplinan para guru tentu tidak lepas dari kepemimpinan, Keteladanan, kemampuan persuasif, ketegasan, pengawasan pemimpin pada bawahannya adalah hal yang sangat mempengaruhi kedisiplinan guru.

Seorang pemimpin dapat mencerminkan bagaimana kedisiplinan bawahannya, juga dapat menjadi contoh bagi karyawan baik itu contoh yang baik ataupun contoh yang buruk. Besar kecilnya kompensasi juga dapat mempengaruhi disiplin guru, jika kompensasi yang diterima para tenaga pendidiknya baik maka akan timbul kesadaran dan kesediaan para pendidik untuk mematuhi peraturan-peraturan yang ada di madrasah tersebut.

Kepala madrasah merupakan salah satu elemen pokok pendidikan yang bertanggung jawab dalam meninkatkan kualitas pendidikan. Terdapat hubungan erat

1 Undang-Undang Nomor 20 Tahun 2003 tentang Sistem Pendidikan Nasional, Jakarta, Visimedia, 2007), h. 20. 
antara mutu kepala madrasah dengan berbagai aspek kehidupan madrasah seperti disiplin, iklim budaya madrasah, dan prilaku peserta didik. ${ }^{2}$

Dari hasil obsevasi awal, sebagai salah satu madrasah tsanawiyah yang ada di Kecamatan Sakra Timur, MTs NW Selayar dituntut untuk mampu bersaing dengan madrasah umum lainnya. Kepala madrasah dituntut aktif dalam memamfaatkan dan mengolah sumber daya madrasah agar menjadi pemicu bagi peningkatan mutu tenaga pendidik di madrasahnya.

Berangkat dari uraian tersebut, maka peneliti tertarik untuk mengkaji lebih jauh tentang "Manajemen kepala madrasah dalam meningkatkan mutu tenaga pendidik di MTs NW Selayar" tahun 2018.

\section{Konsep Manajemen}

\section{Manajemen}

Manajemen berasal dari bahasa Inggris to manage yang berarti mengatur, mengurus atau mengelola. Menurut Melayu S.P Hasibuan, manajemen adalah suatu ilmu dan seni mengatur proses pemamfaatan sumber daya manusia secara efektif, yang didukung oleh sumber-sumber lain dalam organisasi untuk mencapai tujuan tertentu. ${ }^{3}$

Para ahli memberikan pengertian tentang manajemen, di antaranya adalah sebagai berikut:

Oey Liang Lee menjelaskan bahwa "sebagai seni dan ilmu", dalam manajemen terdapat strategi memamfaatkan tenaga dan pikiran orang lain untuk melaksanakan aktifitas yang diarahkan pada pencapaian tujuan yamg telah ditentukan sebelumnya. Dalam manajemen terdapat teknik-teknik yang kaya akan nilai-nilai kepemimpinan dalam mengarahkan, mempengaruhi, mengawasi, dan mengorganisasikan semua komponen yang saling menunjang untuk mencapaiannya tujuan. ${ }^{4}$ Dimana seorang pemimpin harus mempunyai seni dalam

${ }^{2}$ E. Mulyasa, Menjadi Kepela Madrasah yang Profesional: dalam Konteks Menyukeseskan MBS dan KBK (Bandun: Remaja Rosdakarya, 2005) hlm. 24.

${ }^{3}$ U.Saefullah, Manajemen Pendidikan Islam, (Bandung:CV. Pustaka Setia, 2014),1.

${ }^{4}$ Lee, Oey Liang, Pengantar Manajemen, (Jakarta:Salemba Empat) hlm.15 
melaksanakan tugasnya sebagai pemimpin, dengan demikian akan mudah dalam mengarahkan, mepengaruhi dan mengevaluasi bawahannya.

Ramayulis mendefinisikan Manajemen sebagai "proses pemamfaatan semua sumber daya yang dimiliki umat islam, lembaga pendidikan dan lainnya, baik perangkat keras maupun lunak. Pemamfaatan tersebut dilaksanakan melalui kerjasama dengan orang lain secara efektif dan efesien dan produktif untuk mencapai tujuan tertentu". ${ }^{5}$ Pemikiran manajemen dalam islam bersumber dari nash-nash Al-Quran dan petunjuk-petunjuk As-sunnah dan berdasarkan nilainilai kemanusiaan yang berkembang di masyarakat.

\section{Konsep Kepala Madrasah}

Kepala madrasah adalah jabatan pemimpin yang tidak bisa diisi oleh orangorang tanpa didasarkan atas pertimbangan-pertimbangan. Siapapun yang diangkat menjadi kepala sekolah harus ditentukan melalui prosedur serta persyaratanpersyaratan tertentu seperti: latar belakang pendidikan, pengalaman, usia, pangkat dan integritas. Oleh sebab itu kepala madrasah pada hakikatnya adalah pejabat formal, sebab pengangkatnya melalui suatu proses dan prosedur yang didasarkan atas peraturan-peraturan yang berlaku. ${ }^{6}$

\section{Fungsi Kepala Madrasah}

\section{a. Kepala Madrasah Sebagai Educator}

Kegiatan belajar mengajar merupakan inti dari proses pendidikan dan guru merupakan pelaksana dan pengembang utama kurikulum di madrasah ${ }^{7}$ kepala madrasah menunjukkan komitmen tinggi dan fokus terhadap pengembangan kurikulum dan kegiatan belajar-mengajar tentu akan meperhatikan tingkat kompetensi yang dimiliki oleh guru, sekaligus juga akan senantiasa berusaha memfasilitasi dan mendorong agar para guru dapat secara terus menerus meningkatkan kompetensinya. Demikian kegiatan belajar mengajar dapat berjalan dengan efektif dan efesien.

${ }^{5}$ Ramayulis, Haji, Ilmu Pendidikan Islam, Cet, ke-10, (Jakarta:kalam Mulia, 2013), 372.

${ }^{6}$ Wahjosumidjo, kepemimpinan kepala sekolah, (jakarta:PT.Raja Grafindo Persada, 2011),,84-

85.

${ }^{7}$ Ibid, hlm.98 


\section{b. Kepala Madrasah Sebagai Manajer}

Kepala sekolah sebagai manajer mempunyai peran yang menetukan dalam pengelolaan manajemen madrasah, berhasil tidaknya tujuan madrasah dapat dipengaruhi bagaimana kepala madrasah menjalankan fungsi-fungsi manajemen. Fungsi-fungsi manajemen tersebut adalah planing (perencanaan), organizing (pengorganisasian), actuating (penggerakan) dan controlling (pengontrol). ${ }^{8} \mathrm{Hal}$ senada juga kutipan dari Ronins, Wegner,dan Hollenbeck tugas kepala sekolah sebagai manajer adalah mencakup fungsi-fungsi pokok atau proses manajemen, yang terdiri dari perencanaan, pengorganisasian, pelaksanaan, pengoodinasian, pengawasan dan evaluasi. ${ }^{9}$

Sesuai dengan yang ditetapkan dalam penilaian kinerja kepala madrasah, harus memiliki kemampuan dalam melaksanakan tugas-tugas kepemimpinannya dengan baik, yang diwujudkan dalam kemampuan menyusun program madrasah, organisasi personalia, memberdayakan tenaga kependidikan, dan memberdayakan sumberdaya madrasah secara optimal.

\section{Tenaga pendidik}

Undang-undang nomor 20 tahun 2003, tentang Sistem Pendidikan Nasional, pasal 39 ayat $1 .^{10}$ Tenaga Pendidik merupakan tenaga profesional yang bertugas merencanakan dan melaksanakan proses pembelajaran, menilai hasil pembelajaran, melakukan bimbingan dan pelatihan, serta melakukan penilitian dan pengabdian kepada masyarakat. Pada format pengelolaan pendidikan yang sentralistik, sekolah menjadi unit birokrasi dan tenaga pendidik (guru) sering diposisikan sebagai karyawan birokrasi pemerintah. Sebaliknya pada format pengelolaan pendidikan yang desentralisasikan, sekolah dikonsepkan sebagai unit akademik dan tenaga pendidik (guru) merupakan tenaga profesional. Supaya mempunyai lulusan peserta didik yang diharapkan maka sekolah harus meningkatkan mutu guru.

\footnotetext{
${ }^{8}$ Abdullah Munir, Menjadi Kepala Sekolah yang Efektif.hlm.16

${ }^{9}$ Prim MasrokanMuthor, Manajemen Mutu Sekolab Strategi Peningkatan Mutu dan Dayasaing Lembaga Pendidikan Islam. (yogyakarta:AR-Ruzz Media, 2013.hlm.246 2007), h. 20

${ }^{10}$ Undang-Undang Nomor 20 Tabun 2003 tentang Sistem Pendidikan Nasional, (Jakarta, Visimedia,
} 
Mutu

Mutu memiliki pengertian yang bervariasi dan beragam. Seperti yang dinyatakan oleh Nomi Pfeffer dan Anna Cote dalam Edward Sallis, bahwa mutu adalah konsep yang licin. Mutu merupakan suatu ide yang dinamis. Mutu hanyalah sebuah kata bernada moral tin namun tidak memiliki nilai praktis. ${ }^{11}$ Beberapa kebingungan terhadap makna mutu bisa muncul karena mutu dapat digunakan sebagai suatu konsep ideal yang absolut dan relativ. ${ }^{12}$

Dalam definisi yang absolut, sesuatu yang bermutu merupakan bagian yang standar yang sangat tinggi dan tidak dapat diungguli. Produk-produk yang bermutu adalah sesuatu yang dibuat dengan sempurna dan dengan biaya yang mahal. Sebagai contoh mobil yang bermutu adalah mobil hasil rancangan istimewa dan mahal. Mutu dalam pandangan ini adalah suatu yang sangat mahal dan langka. ${ }^{13}$ Dalam pengertian demikian, mutu lebih tepat disebut dengan High Quality atau Top Quality.

\section{HASIL PENELITIAN}

Pada bab ini dipaparkan hasil penelitian dan pembahasan. Hasil penelitian dan pembahasan tentang manajemen kepala madrasah dalam peningkatan mutu tenaga pendidik di MTs NW Selayar dilakukan dengan urutan a) Strategi kepala madrasah dalam meningkatkan mutu tenaga pendidik; b) Kepala madrasah melakukan evaluasi terhadap kinerja tenaga pendidik dan c) Kendala kepala madrasah dalam meningkatkan mutu tenaga pendidik.

\section{Strategi Kepala Madrasah Meningkatkan Mutu Tenaga Pendidik MTs NW Selayar}

Pelaksanaan peningkatan mutu guru diupayakan makin lama mampu mandiri (untuk hal-hal tertentu) tanpa banyak bergantung kepada pihak lain. Pelaksanaan peningkatan mutu tenaga pendidik juga harus menjalin kerjasama atau kemitraan

\footnotetext{
${ }^{11}$ Edward Sallis, Total Quality Management In Education, cet. Xii (Yogyakarta: IRCiSod, $2012,, 50$

12 Sebagai sebuah konsep yang absolut, mutu sama halnya dengan sifat baik, cantik, dan benar. Misalnya mobil yang mahal dan hotel yang mewah akan dianggap sebagai suatu yang bermutu.

${ }^{13}$ Ibid, hlm.53
} 
dengan stakeholders untuk menghasilkan tujuan yang optimal. Demikian juga suatu program harus dilaksanakan dengan melibatkan semua pihak secara proporsional dan professional, sehingga menumbuhkan semangat partisipasi.

Pelaksanaan mutu tenaga pendidik di madrasah MTs NW Selayar antara lain dilakukan dengan mengikutkan para tenaga pendidik dalam forum ilmiah (seminar, diklat, lokakarya, wokshop dan kursus), pembelian buku baru yang menunjang terhadap kinerja tenaga pendidik, hal ini seperti yang dipaparkan oleh Bapak Jum'ah sebagai berikut:

"Program ataupun usaha untuk meningkatkan mutu tenaga pendidik yang saya lakukan selaku kepala madrasah yang dibantu wakil kepala madrasah dan jajaran yang terkait, adalah mengikutkan seminar, diklat, kursuskursus, dan pembelian buku mata pelajaran kepada tenaga pendidik". ${ }^{14}$

Dan peneliti mengamati dan melihat kepala madrasah mengumpulkan berkasberkas yang akan di ajukan untuk para tenaga pendidik yang akan mengikuti seminar dan diklat yang akan di adakan di kota selong.15 Ini adalah salah satu usaha dari kepala madrasah untuk meningkatkan mutu tenaga pendidik di MTs NW Selayar.

Secara detail, usaha pembinaan dan pengembangan mutu tenaga pendidik yang dilakukan oleh MTs NW Selayar adalah sebagai berikut:

a. Mengadakan dan mengikutsertakan tenaga pendidik dalam forum ilmiah (Pendidikan dan latihan (up grading/inservice training), workshop, dan seminar) Pendidikan dan latihan (inservice training/up grading) merupakan salah satu cara untuk meningkatkan kemampuan/ profesionalisme tenaga pendidik. Selain meningkatkan kemampuan kinerja guru dalam kegiatan belajar mengajar (KBM), pendidikan dan latihan juga bermanfaat bagi tenaga pendidik untuk memperoleh informasi baru yang berkaitan dengan pendidikan, pengajaran, metode-metode yang baru dalam bidang pembelajaran sekaligus bermanfaat bagi tenaga pendidik yang sedang menyusun portofolio

14 Wawancara dengan bapak Jum'ah selaku kepala madrash MTs NW Selayar,18 april 2018 pukul 11.00-11.30 wita

15 Observasi, dikutip pada tanggal 18 april 2018 
sertifikasi tenaga pendidik sebagai poin tambahan untuk memenuhi poin yang ditetapkan untuk mencapai kelulusan.

Mengenai hal ini, hasil wawancara dengan Bapak Jamaluddin selaku tenaga pendidik di MTs NW Selayar, Bapak Jamaluddin mengatakan:

"Dalam rangka meningkatkan kinerja tenaga pendidik, kami selalu dikirim bergiliran sesuai dengan bidang studi kami masing-masing untuk mengikuti pelatihan, seminar, lokakarya, workshop ataupun kegiatan pendidikan lainnya baik yang diadakan oleh balai diklat (pemerintah), penyelenggara swasta maupun diklat yang diadakan secara mandiri oleh madrasah", 16

Lebih lanjut kepala MTs NW Selayar menjelaskan bahwa dalam rangka meningkatkan kinerja tenaga pendidik pada bulan Januari 2018, MTs NW Selayar menyelenggarakan Diklat tentang Penelitian Tindakan Kelas (PTK) secara mandiri, hal ini sesuai dengan pernyataan guru MTs NW Selayar, Ibu Siti Syari'ah yang mengatakan:

"Pada bulan Januari 2018, MTs NW Selayar menyelenggarakan Diklat secara mandiri tentang penyusunan Penelitian Tindakan Kelas (PTK) hal ini dimaksudkan agar tenaga pendidik di madrasah ini lebih memahami dan dapat melakukan penelitian tindakan kelas sehingga proses belajar mengajar (PMB) dapat berjalan dengan baik dan lancar" ${ }^{17}$

- Lebih lanjut Ibu Siti Syari'ah, yang pernah diikutkan dalam pelatihan dan seminar mengungkapkan:

"Kepala madrasah sering menunjuk guru-guru secara bergiliran untuk ikut pendidikan dan latihan, workshop, dan seminar yang sesuai dengan mata pelajaran dan yang relevan dengan kependidikan

${ }^{16}$ Wawancara dengan bapak Bapak Jamaluddin selaku guru di MTs NW Selayar,18 april 2018 pukul $11.30-11.40$ wita

17 Wawancara dengan Siti Syari'ah selaku guru MTs NW Selayar, 18 april 2018 pukul 11.3012.00wita 
dan pengembangan kinerja tenaga pendidik. Para tenaga pendidik yang sudah mengikuti pelatihan diminta untuk menjelaskan hasil dari pelatahan dan seminar kepada tenaga pendidik yang lain dalam rapat madrasah, di MTs NW Selayar". ${ }^{18}$

Dari pernyataan di atas menunjukkan bahwa Kepala Madrasah selaku pengambil kebijakan (policy makers) mengikutkan para tenaga pendidik dalam diklat, seminar, maupun workshop sebagai salah satu upaya ataupun strategi untuk meningkatkan mutu guru MTs NW Selayar selanjutnya mengenai pembiayaanya, hasil wawancara dengan kepala madrasah di rumah beliau, Bapak Jum'ah mengatakan:

"Dalam hal pembiayaan mengikutsertakan tenaga pendidik dalam pelatihan, seminar, maupun lokakarya pihak madrasah membiayai secara penuh semua biaya yang timbul akibat acara tersebut, dalam artian para tenaga pendidik yang diikutkan dalam acara pelatihan tersebut secara gratis, sehingga guru lebih bersemangat dan tidak mengalami kendala dalam hal biaya",19

Untuk pengimbasannya, kepala madrasah selanjutnya memerintahkan kepada tenaga pendidik yang sudah diikutsertakan dalam pelatihan, seminar, maupun lokakarya untuk menyampaikan ataupun mengimbaskan ilmunya kepada tenaga pendidik lain yang tidak mengikutinya.

\section{a. Meningkatkan Tunjangan Kesejahteraan Tenaga Pendidik}

Tunjangan kesejahteraan guru termasuk bagian yang menjadi prioritas utama kepala madrasah MTs NW Selayar dalam meningkatkan mutu tenaga pendidik, berkaitan dengan hal ini, Bapak Saparwadi selaku tenaga pendidik di MTs NW Selayar menyatakan:

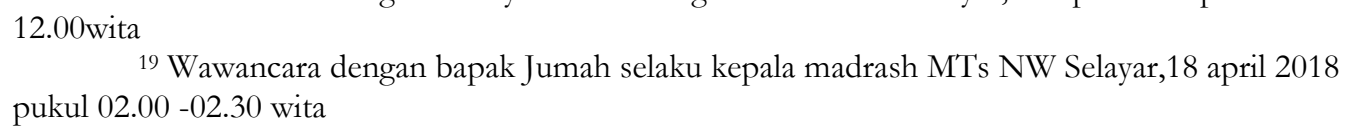


"Kami sering diberikan tunjangan kesejahteraan oleh bapak kepala madrasah MTs NW Selayar, dan kami diberi tugas tambahan mengajar, PIB, binsus, maupun yang terlibat dalam kegiatan intrakurikuler dan ekstra kurikuler dan kami diberi tambahan insentif dan transport diluar gaji pokok kami”, ${ }^{20}$

Dari pernyataan di atas dapat dipahami bahwa pemberian tunjangan kesejahteraan merupakan bagian dari usaha ataupun strategi kepala madrasah dalam meningkatkan kinerja tenaga pendidik MTs NW Selayar. Dan dipertegas oleh pernyataan Bapak Lalu Hendra selaku wakil kepala madrasah:

"Tunjangan insentif dan transport yang diberikan kepada tenaga pendidik semata-mata untuk membantu meningkatkan kesejahteraan guru agar kinerja dan semangat tenaga pendidik menjadi meningkat, disamping itu, tunjangan kesejahteraan tenaga pendidik diberikan agar para tenaga pendidik menjadi fokus terhadap pekerjaannya supaya tidak disibukkan dengan mencari uang tambahan diluar tugas utamanya yaitu mengajar". ${ }^{21}$

Dengan adanya perhatian kepala madrasah terhadap kesejahteraan tenaga pendidik, maka para tenaga pendidik di MTs NW Selayar diharapkan lebih berkonsentrasi terhadap pekerjaannya sebagai seorang pendidik dan selalu termotivasi untuk meningkatkan kemampuan dan keahliannya demi tercapainya visi dan misi madrasah ke depan.

b. Mengikutkan Dalam Program Sertifikasi Tenaga Pendidik

Usaha lain yang dilakukan kepala MTs NW Selayar dalam meningkatkan mutu tenaga pendidik adalah dengan mengikutkan tenaga pendidik dalam program sertifikasi tenaga pendidik. Dalam hal ini, Bapak Jum'ah menjelaskan: "Semua tenaga pendidik disini saya daftarkan untuk mengikuti

${ }^{20}$ Wawancara dengan Bapak Saparwadi selaku tenaga pendidik MTs NW Selayar,18 april 2018 pukul $03.00-03.30$ wita

${ }^{21}$ Wawancara dengan bapak Lalu Hendra selaku wakil kepala madrash MTs NW Selayar,19 april 2018 pukul $08.00-09.00$ wita 
ujian portofolio sertifikasi tenaga pendidik, dan alhamdulillah sudah 14 orang yang berhasil lulus dalam sertifikasi tenaga pendidik termasuk saya”22

Kebijakan kepala madrasah dalam mengikutkan tenaga pendidik dalam program sertifikasi adalah sebuah tindakan yang membantu tenaga pendidik untuk memperoleh pengakuan secara resmi dengan diterbitkannya piagam/sertifikat sebagai tenaga tenaga pendidik yang profesional. Dengan adanya dorongan dan motifasi yang kuat dari kepala madrasah, tenaga pendidik MTs NW Selayar akan lebih bersemangat dalam mempersiapkan bahan-bahan untuk mengikuti ujian sertifikasi, sehingga tenaga pendidik yang lolos sertifikasi secara de jure diakui oleh undang-undang sebagai tenaga pendidik yang profesional.

Berdasarkan hasil wawancara, studi dokumentasi dan pengamatan yang dilakukan tentang strategi kepala madrasah melaksanakan peningkatan mutu tenaga pendidik MTs NW Selayar, diketahui bahwa kepala madrasah sudah melaksanakan upaya dan strategi untuk peningkatan mutu tenaga pendidik tersebut. Pelaksanaan peningkatan mutu tenaga pendidik di MTs NW Selayar, antara lain dilakukan strategi mengikutkan para tenaga pendidik dalam forum ilmiah (seminar, diklat, lokakarya, wokshop dan kursus), pembelian buku baru yang menunjang terhadap kinerja guru dan mengikutkan tenaga pendidik dalam program sertifikat profesi.

\section{Kepala Madrasah Melakukan Evaluasi Peningkatan Mutu Tenaga Pendidik MTs NW Selayar}

Dalam mengembangkan dan meningkatkan mutu tenaga pendidik, evaluasi secara transparan dan obyektif mutlak diperlukan, dan evaluasi merupakan kegiatan akhir dari proses dan tindakan manajemen. Evaluasi atau penilaian terhadap tenaga pendidik biasanya lebih difokuskan pada prestasi individu tenaga pendidik terutama dalam kegiatan proses belajar mengajar, dan peran sertanya dalam kegiatan pendidikan di madrasah. MTs

22 Wawancara dengan bapak Jumah selaku kepala madrash MTs NW Selayar,20 april 2018 pukul $08.00-09.00$ wita 
NW Selayar dibawah pimpinan Bapak Jum'ah, sebagai kepala madrasah selalu mengadakan penilaian dan evaluasi terhadap tenaga pendidik terutama menyangkut mutu tenaga pendidik di madrasah. Berkaitan dengan hal ini kepala MTs NW Selayar, Bapak Jum'ah menyampaikan:

"Untuk melihat perkembangan mutu tenaga pendidik, terutama dalam proses belajar mengajar di kelas dan kinerja tenaga pendidik di madrasah, saya selaku kepala selalu memantau dan menilai tenaga pendidik dengan melakukan supervisi terhadap tenaga pendidik, baik melalui teknik kunjungan kelas, pembicaraan secara individu maupun dalam diskusi kelompok dalam acara silaturrahmi antar tenaga pendidik",23

Dari pernyataan di atas dapat dipahami bahwa untuk melihat perkembangan mutu tenaga pendidik, terutama dalam proses belajar mengajar di kelas dan kinerja tenaga pendidik di madrasah, kepala Madrasah MTs NW Selayar selalu memantau dan menilai tenaga pendidik dengan melakukan supervisi terhadap tenaga pendidik. Lebih lanjut Bapak Jumah menjelaskan,

"Disamping melakukan kegiatan supervisi pendidikan dalam melakukan penilaian pribadi, saya setiap hari mengecek kehadiran tenaga pendidik melalui presensi kehadiran tenaga pendidik di kelas, ketika saya mendapatkan tenaga pendidik yang mempunyai masalah, saya memanggilnya ke kantor untuk menanyakan problem-problem apa yang sedang dihadapi, kemudian saya mengajak diskusi untuk mencari jalan keluarnya, selain itu saya juga mengoptimalkan layanan bimbingan konseling untuk mengatasi persoalan-persoalan yang dihadapi oleh tenaga pendidik". ${ }^{24}$

${ }^{23}$ Wawancara dengan bapak Jumah selaku kepala madrash MTs NW Selayar,20 april 2018 pukul $09.00-09.30$ wita

${ }^{24}$ Wawancara dengan bapak Jumah selaku kepala madrash MTs NW Selayar,20 april 2018 pukul $10.00-10.30$ wita 
Penilaian terhadap tenaga pendidik yang dilakukan kepala madrasah MTs NW Selayar untuk mengetahui hal-hal yang menyangkut pribadi, status, pekerjaan, prestasi kerja maupun perkembangan tenaga pendidik sehingga dapat dikembangkan pertimbangan nilai obyektif dalam mengambil tindakan terhadap seorang tenaga khusus yang diperlukan untuk mempertimbangkan; kenaikan pangkat, gaji berkala, penghargaan, pemindahan jabatan (promosi), perpindahan wilayah kerja (mutasi).

Selain melakukan supervisi, metode yang dipakai untuk menilai kondisi dan perkembangan tenaga pendidik baik kinerja dan kompetensinya adalah dengan membuat format penilaian yang sudah dibakukan oleh pemerintah untuk menilai kinerja tenaga pendidik dan staf dilingkungan Departemen Pendidikan yaitu Daftar Penilaian Kinerja (DP3).Penilaian ini biasanya dilakukan disetiap akhir tahun.

Pernyataan kepala madrasah dan wakil kepala madrasah di atas sesuai dengan hasil pengamatan selama melakukan penelitian dimana Bapak Jum'ah, S.Pd, sebagai kepala MTs NW Selayar setiap pagi selalu berkeliling madrasah untuk mengecek satu persatu ruang kelas untuk memastikan apakah ada ruang kelas yang kosong/ tenaga pendidik yang tidak masuk kelas. $^{25}$

Terkait dengan hal ini, pada tanggal 21 April 2018, Bapak kepla madrasah terlihat mondar mandir mengelilingi seluruh kelas yang ada di MTs NW Selayar, dan beliaupun berhenti di depan kelas X karena kelas tersebut tampak kosong karena tenaga pendidik Bahasa Inggris hari itu absen mengajar, kemudian beliau mengucapkan salam "Assalamu ealaikum?" kemudian para siswa kelas tersebut seperti dikomando mungkin dari saking gembirannya diajar langsung oleh kepala madrasah "wa"alaikum salam". Kemudian beliau bertanya kabar seluruh sisiwa kelas X, dan kepala madrasah juga bertanya seputar cara mengajar tenaga pendidik bahasa Inggris ini. Ternyata mayoritas para siswa menjawab menyenangkan.

25 Observasi, di MTs NW Selayar pada tanggal 20 april 2018 
Dari hasil wawancara, studi dokumentasi dan pengamatan yang dilakukan tentang strategi kepala madrasah melaksanakan monitoring dan evaluasi peningkatan mutu tenaga pendidik MTs NW Selayar, menunjukkan bahwa dalam meningkatkan mutu tenaga pendidik, Kepala MTs NW Selayar mengadakan evaluasi terhadap perkembangan tenaga pendidik. Evaluasi yang dilakukan adalah dengan melakukan supervisi pendidikan terhadap para tenaga pendidik. Teknik supervisi yang digunakan ada tiga yaitu: teknik kunjungan kelas; pembicaraan pribadi dan diskusi kelompok. Sedangkan untuk pendekatan yang digunakan adalah secara langsung (directif) dan tidak langsung (non directif).

Sasaran maupun aspek yang dievaluasi adalah kehadiran tenaga pendidik (presensi), kinerja tenaga pendidik, prestasi dan perkembangan siswa, catatan kelas dalam hal ini adalah tes harian, mingguan, bulanan hingga semesteran, silabus dan RPP guru. Selanjutnya ketika ada tenaga pendidik yang mempunyai masalah, kepala MTs NW Selayar memanggil secara pribadi masalah apa yang sedang dihadapi tenaga pendidik tersebut, kemudian dicarikan pemecahannya.

Dalam mengevaluasi tenaga pendidik secara kelompok adalah diadakannya forum silaturrahmi para tenaga pendidik yang diikuti oleh kepala madrasah, komite dan tenaga kependidikan secara bergiliran setiap tiga bulan untuk melakukan koordinasi dan pemecahan masalah yang ada. Evaluasi tersebut diharapkan dapat membantu menyelesaikan permasalahan yang ada dan untuk membina serta meningkatkan kinerja tenaga pendidik ke depan sesuai dengan kebutuhan masyarakat. 


\section{KESIMPULAN}

Simpulan secara umum penelitian ini yaitu Manajemen kepala madrasah dalam peningkatan mutu tenaga pendidik di MTs NW Selayar dilakukan dengan melakukan strategi peningkatan mutu tenaga pendidik, melaksanakan evaluasi terhadap tenaga pendidik, dan juga terdapat kendala dan solusi untuk penerapan manajemen kepala madrasah dalam meningkatkan mutu tenaga pendidik di MTs NW Selayar.

Simpulan khusus penelitian sebagai berikut:

Pertama, strategi kepala madrasah dalam meningkatkan mutu tenaga pendidik di MTs NW Selayar dilaksanakan dengan mengikutkan para tenaga pendidik dalam forum ilmiah (seminar, diklat, lokakarya, wokshop dan kursus), studi lanjut, revitalisasi MGMP, tunjangan kesejahteraan, penyediaan fasilitas penunjang seperti penyediaan fasilitas internet untuk mengakses informasi baru, pembelian buku baru yang menunjang terhadap kinerja tenaga pendidik dan mengikutkan guru dalam program sertifikat profesi.

Kedua, manajemen kepala madrasah dalam melaksanakan evaluasi peningkatan mutu tenaga pendidik di MTs NW Selayar dilakukan dengan mengadakan evaluasi terhadap perkembangan mutu tenaga pendidik. Evaluasi yang dilakukan adalah dengan melakukan supervisi pendidikan terhadap para tenaga pendidik. Sasaran maupun aspek yang dievaluasi adalah kehadiran tenaga pendidik (presensi), kinerja tenaga pendidik, prestasi dan perkembangan siswa, catatan kelas dalam hal ini adalah tes harian, mingguan, bulanan hingga semesteran, silabus dan RPP tenaga pendidik. Selain menggunakan supervisi pendidikan, kepala madrasah juga melakukan penilaian dengan menggunakan format penilaian yang sudah dibakukan oleh pemerintah yang dikenal dengan Daftar Penilaian Kinerja (DP3).

Ketiga, kendala yang dihadapi kepala madrasah untuk meningkatkan mutu tenaga pendidik adalah masih adanya tenaga pendidik yang rendah kesadarannya akan peningkatan mutu tenaga pendidik, masih adanya tenaga pendidik yang kurang berkompeten serta masih kurangnya jumlah tenaga pendidik sesuai kebutuhan. Solusi yang ditempuh Kepala MTs NW Selayar dalam mengatasi kendala 
peningkatan tenaga pendidik adalah dengan secara terus menerus melakukan komunikasi dan kampanye budaya mutu pendidikan untuk tenaga pendidik yang masih rendah kesadarannya dan mengajukan permohonan tenaga tenaga pendidik melalui Dinas Pendidikan Kabupaten Lombok Timur, serta dengan melakukan pengangkatan tenaga pendidik honor untuk mengatasi kekurangan jumlah tenaga pendidik.

\section{DAFTAR PUSTAKA}

Undang-Undang Nomor 20 Tabun 2003 tentang Sistem Pendidikan Nasional, (Jakarta, Visimedia, 2007),

E. Mulyasa, Menjadi Kepela Madrasah yang Profesional: dalam Konteks Menyukseskan MBS dan KBK (Bandun: Remaja Rosdakarya, 2005)

U.Saefullah, Manajemen Pendidikan Islam, (Bandung:CV. Pustaka Setia, 2014),

Lee, Oey Liang, Pengantar Manajemen, (Jakarta:Salemba Empat)

Ramayulis, Haji, Ilmu Pendidikan Islam, Cet, ke-10, (Jakarta:kalam Mulia, 2013)

Wahjosumidjo, kepemimpinan kepala sekolah, (jakarta:PT.Raja Grafindo Persada, 2011)

Prim MasrokanMuthor, Manajemen Mutu Sekolah Strategi Peningkatan Mutu dan Dayasaing Lembaga Pendidikan Islam. (yogyakarta:AR-Ruzz Media, 2013

Edward Sallis, Total Quality Management In Education, cet. Xii (Yogyakarta: IRCiSod, 2012 